\title{
Erratum to: Developing a Skilled Workforce Through Technical and Vocational Education and Training in the Philippines
}

\author{
Kiran S. Budhrani, Mark M. D'Amico, and Jose Lloyd D. Espiritu
}

\section{Chapter 39 in: R. L. Raby, E. J. Valeau (eds.), Handbook of Comparative Studies on Community Colleges and Global Counterparts, Springer International Handbooks of Education, https://doi.org/10.1007/978-3-319-50911-2_28}

Owing to an error on the part of editors, the author name was published as Marc D’Amico. His name has been updated as Mark M. D’Amico

The updated online version of this chapter can be found at https://doi.org/10.1007/978-3-31950911-2_28

K. S. Budhrani $(\square)$

Center for Teaching and Learning, University of North Carolina at Charlotte, Charlotte, NC, USA e-mail: kbudhran@uncc.edu

M. M. D'Amico

Department of Educational Leadership, University of North Carolina at Charlotte, Charlotte, NC, USA

e-mail:mmdamico@uncc.edu

\section{J. L. D. Espiritu}

Psychology Department, De La Salle University, Manila, Philippines e-mail: espiritu.1loyd@gmail.com 